WellBeing International

WBI Studies Repository

$10-1984$

\title{
Isolation of Lactoferrin and its Concentration in Sows' Colostrum and Milk During a 21-Day Lactation
}

J. I. Elliot

Agriculture Canada

B. Senft

Agriculture Canada

G. Ernhardt

Agriculture Canada

D. Fraser

Agriculture Canada

Follow this and additional works at: https://www.wellbeingintlstudiesrepository.org/nutrit

Part of the Animal Studies Commons, Other Animal Sciences Commons, and the Other Nutrition

Commons

\section{Recommended Citation}

Elliot, J. I., Senft, B., Erhardt, G., \& Fraser, D. (1984). Isolation of lactoferrin and its concentration in sows' colostrum and milk during a 21-day lactation. Journal of animal science, 59(4), 1080-1084.

This material is brought to you for free and open access by WellBeing International. It has been accepted for inclusion by an authorized administrator of the WBI Studies Repository. For more information, please contact wbisr-info@wellbeingintl.org.

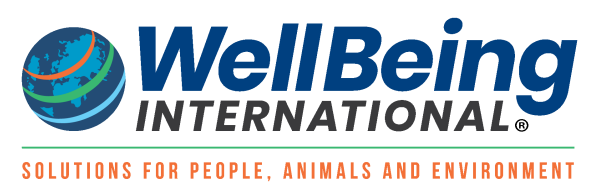




\title{
ISOLATION OF LACTOFERRIN AND ITS CONCENTRATION IN SOWS' COLOSTRUM AND MILK DURING A 21-DAY LACTATION ${ }^{1,2}$
}

\author{
J. I. Elliot, B. Senft ${ }^{3}$, G. Erhardt and D. Fraser \\ Animal Research Centre, Agriculture Canada, \\ Ottawa, Ontario K1A 0C6 \\ and \\ University of Giessen, D-6300 \\ Giessen, West Germany
}

\section{Summary}

Levels of lactoferrin, an Fe-binding protein with bacteriostatic properties, were determined in the colostrum and milk of Yorkshire sows during a 21-d lactation. Lactoferrin levels averaged 1,100 to $1,300 \mu \mathrm{g} / \mathrm{ml}$ near the time of farrowing, then declined sharply during the first week of lactation. Concentration of lactoferrin showed considerable variation among sows, but not among teat positions (anterior to posterior). A method for isolating high purity swine lactoferrin is described.

(Key Words: Colostrum, Lactation, Lactoferrin, Milk, Sow, Teat Position.)

\section{Introduction}

Lactoferrin is an Fe-binding protein with bacteriostatic properties, found in the whey fraction of milk in humans and domestic livestock species (Oram and Reiter, 1968; Masson and Heremans, 1971; Senft and Klobasa, 1973; Schanbacher and Smith, 1975). It has been suggested that the bacteriostatic action of lactoferrin is important in the prevention of udder infections such as mastitis in cattle (Harmon et al., 1975), and in the prevention of intestinal disturbances in the neonate (Bullen et

\footnotetext{
${ }^{1}$ Contribution No. 1199, Animal Research Centre.

${ }^{2}$ The authors are grateful to $\mathbf{R}$. W. Allen for assistance in the collection and analysis of samples, to Dr. B. K. Thompson for discussing the statistical analyses, and to Dr. A. Grunder for assistance and discussion.

${ }^{3}$ Dr. Senft was a visiting scientist at the Animal Research Centre in 1981.

Received November 28, 1983.

Accepted April 6, 1984.
}

al., 1972). Law and Reiter (1977) suggested that this protein might be used as a bacteriostatic agent in milk replacers used for artificial rearing of neonates. However, this has apparently never been attempted even though there is suitable methodology for isolating lactoferrin in quantity from the whey fraction of cows' milk.

There is only one report in the literature on the concentration of lactoferrin in the mammary secretions of sows throughout lactation (Masson and Heremans, 1971). The results show high concentrations of lactoferrin in colostrum, with lower levels in normal milk. However, the data were based on pooled milk samples taken at uncertain times throughout lactation. Roberts and Boursnnell (1975) calculated a concentration of $.6 \mathrm{mg}$ lactoferrin $/ \mathrm{ml}$ whole milk, based on the amount of protein isolated.

Lactoferrin has potential use as a bacteriostatic agent in milk replacers, as part of an ongoing program to develop procedures and diets for the artificial rearing of piglets (Senft and Klobasa, 1971; Elliot et al., 1978). In order to provide a basis for future experiments the following study was undertaken to establish a method for isolating lactoferrin from sows' milk, and to investigate the concentration of lactoferrin in the mammary secretions of sows throughout lactation.

\section{Materials and Methods}

All samples were obtained from Yorkshire sows from the Animal Research Centre minimaldisease herd. Farrowings were attended to determine the exact time of parturition.

To establish lactoferrin concentration at different stages of lactation, samples of mammary secretion were collected from nine sows on 13 occasions: Within $12 \mathrm{~h}$ prefarrowing, 
immediately postfarrowing (within $1 \mathrm{~h}$ after the afterbirth was expelled), $12 \mathrm{~h}$ postpartum, and on $d 1,2,3,4,5,6,7,11,14$ and 21 of lactation. At least $50 \mathrm{ml}$ of mammary secretion were obtained from each sow at each sampling time by manual expression from randomly selected teats. After the immediate pre- and postfarrowing periods, milk letdown was induced by an im injection of $40 \mathrm{u}$ oxytocin. Samples were stored frozen at $-20 \mathrm{C}$.

To establish teat-to-teat variation in lactoferrin content, samples were collected from each teat on one side of six additional sows. All the samples were collected by hand milking during farrowing (after the expulsion of the first pig and before expulsion of the afterbirth) without injected oxytocin.

Preparation and Characterization of Swine Lactoferrin. Sows' colostrum was used for the isolation of lactoferrin. Samples were centrifuged $(17,000 \times \mathrm{g}, 4 \mathrm{C}, 40 \mathrm{~min})$ so that the fat formed a layer at the top of the milk. The fat was then drawn off using an aspirator. The milk was adjusted to $\mathrm{pH} 7.0$ by $\mathrm{KHCO}_{3}$, and the Fe-binding protein lactoferrin was saturated with $\mathrm{Fe}$ using ammonium ferrous sulfate (8.6 $\mathrm{mg} / \mathrm{ml}$ ). Six grams of Sephadex $\mathrm{CM}-50^{4}$ were added to $500 \mathrm{ml}$ defatted milk at room temperature, mixed for $2 \mathrm{~h}$ and then allowed to settle. The supernatant milk was carefully decanted and the pink gel that remained was washed first three times on a glass filter funnel (G2, D1) with deionized water, then with a .02

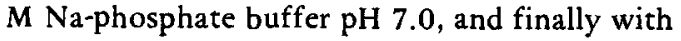
the same buffer containing $.15 \mathrm{M} \mathrm{NaCl}$. About $420 \mathrm{ml}$ of gel was then applied to a column $(90$ $\times 2.5 \mathrm{~cm}$ ) and eluted with a $.02 \mathrm{M} \mathrm{Na}$-phosphate buffer containing a linear $\mathrm{NaCl}$-gradient from .2 to $.5 \mathrm{M}$ at a flow rate of $20 \mathrm{ml} / \mathrm{h}$. Fractions ( 3 $\mathrm{ml}$ ) were collected with an Eldex Universal Fraction Collector Model 4-11, and were read at $280 \mathrm{~nm}$ to establish the presence of protein using a Beckman Model 25 spectrophotometer. Lactoperoxidase was eluted in the first peak of protein (fractions 80 to 110 ), and the second peak (fractions 120 to 240 ) contained lactoferrin. The lactoferrin containing fractions were pooled, concentrated by ultrafiltration and dialysed against deionized water.

\footnotetext{
${ }^{4}$ Pharmacia Fine Chemicals, Uppsala, Sweden.

${ }^{5}$ BioRad Laboratories, Mississauga, Ontario.

${ }^{6}$ Hansens Laboratories Inc., Milwaukee, WI.
}

Further purification of the lactoferrin preparation was accomplished on a $40 \times 2.5 \mathrm{~cm}$ column of Bio-Rex 70 resin $^{5}$ equilibrated with $.01 \mathrm{M} \mathrm{Na-acetate} \mathrm{pH}$ 7.0. After applying about $5 \mathrm{ml}$ of the equilibrated lactoferrin solution, the column was initially eluted with $150 \mathrm{ml}$ of $.4 \mathrm{M} \mathrm{Na}$-acetate $\mathrm{pH} 7.0$, then a linear gradient was applied by mixing $400 \mathrm{ml} .4 \mathrm{M} \mathrm{Na}$-acetate $\mathrm{pH} 7.0$ and $400 \mathrm{ml}$ of $1 \mathrm{M} \mathrm{Na-acetate} \mathrm{pH} 8.0$. Fractions of $3 \mathrm{ml}$ were collected and read as described above to determine the presence of protein. The pink solution comprising the third peak (fractions 90 to 130) contained lactoferrin, which was concentrated by ultrafiltration, dialysed against deionized water and lyophilized. The protein content in the lactoferrin solutions was determined by the method of Lowry et al. (1951).

To estimate its molecular weight, swine lactoferrin was compared with bovine lactoferrin and bovine serum albumin using gel chromatography by the method of Erhardt (1981).

Immunoelectrophoresis was performed by the method of Scheidegger (1955) with antiserum raised in rabbits against swine colostrum.

Quantitative Determination of Swine Lactoferrin. The radial immunodiffusion technique (Mancini et al., 1965) was used to determine the lactoferrin concentration of swine whey. The whey was prepared by precipitating the casein using calf rennin ${ }^{6}$. Diffusion took place within $24 \mathrm{~h}$ at room temperature on glass plates covered with $1.5 \%$ agarose in $.02 \mathrm{M}$ tris-acetatebuffer $\mathrm{pH} 7.9$ and $1 \%$ rabbit anti-swine-lactoferrin. The amount of sample applied was $5 \mu$. Standards were prepared from lactoferrin isolated as previously described. All determinations were made in duplicate. The range for the standards was from $.03 \mathrm{mg} / \mathrm{ml}$ to 4 $\mathrm{mg} / \mathrm{ml}$.

The antisera were obtained from rabbits after sc injection of $2 \mathrm{mg}$ lyophilized lactoferrin diluted in $1 \mathrm{ml}$ distilled water and $1 \mathrm{ml}$ of complete Freund's adjuvant. The injections were repeated four times at 12 -d intervals. Ten days after the last injection, blood was taken from the rabbits by heart puncture.

\section{Results and Discussion}

Preparation and Purification of Lactoferrin. The preparative method used in this investigation makes it possible to use the lactoferrin-free milk for further investigation after having absorbed lactoferrin by Sephadex CM-50. By 


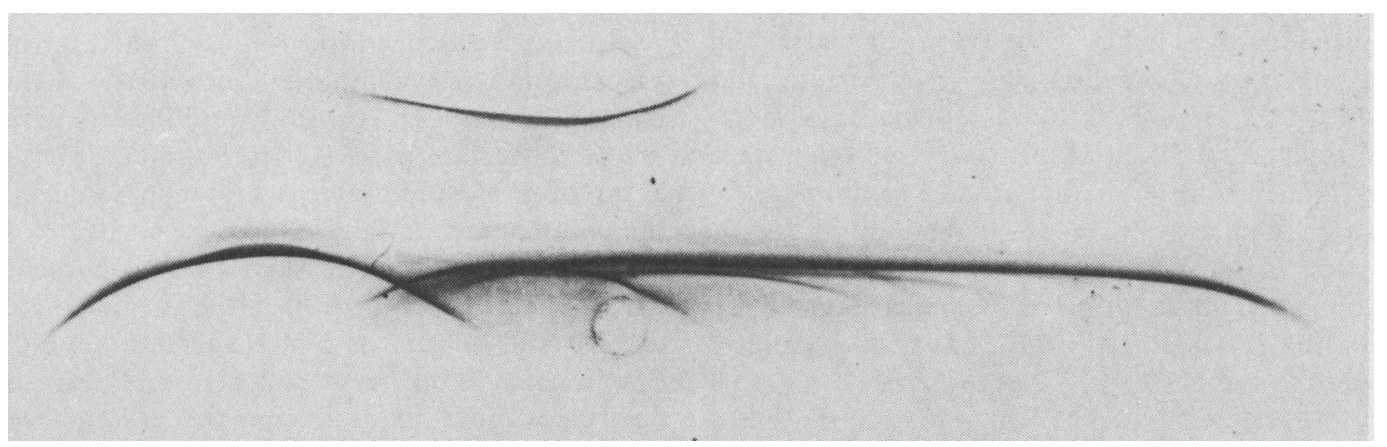

Figure 1. Immunoelectrophoretic reaction of isolated swine lactoferrin (above) and of swine colostrum (below) to antisera produced in rabbits against swine colostrum.

mixing the resin into the milk, several timeconsuming procedures can be avoided and the economy increased by using $\mathrm{CM}-50$ resin repeatedly.

Using the method described herein, a high purity of lactoferrin can be obtained as shown by immunoelectrophoresis (figure 1). The isolated swine lactoferrin formed a strong precipitation line in the $\beta$-area. For comparison the lactoferrin arc is also visible in the separated colostrum sample. This localization of swine lactoferrin is in accordance with the results of Blanc and Isliker (1961) for human lactoferrin. In contrast, bovine lactoferrin is located in the $\gamma$-region (Butler, 1973).

Gel chromatography showed that swine lactoferrin had an elution pattern similar to that of bovine lactoferrin and bovine serum albumin (figure 2), indicating that swine lactoferrin has a molecular weight of about 70,000 .

Lactoferrin Content of Sows' Milk. The lactoferrin content of mammary secretions from nine sows during a $21-\mathrm{d}$ lactation is presented in figure 3 . Lactoferrin levels remained high $(1,100$ to $1,300 \mu \mathrm{g} / \mathrm{ml})$ near the time of farrowing and for the first $3 \mathrm{~d}$ of lactation, and then declined sharply. Two-way analysis of variance, showed highly significant variation among sows $\left(F_{8}, 95=12.1, P<.001\right)$ and among sampling times $\left(\mathrm{F}_{12}, 95=31.3, \mathrm{P}<.001\right)$. The two sows with the highest levels of lactoferrin had concentrations about twice as high as the sows with the lowest levels $(1,092$ and 1,021

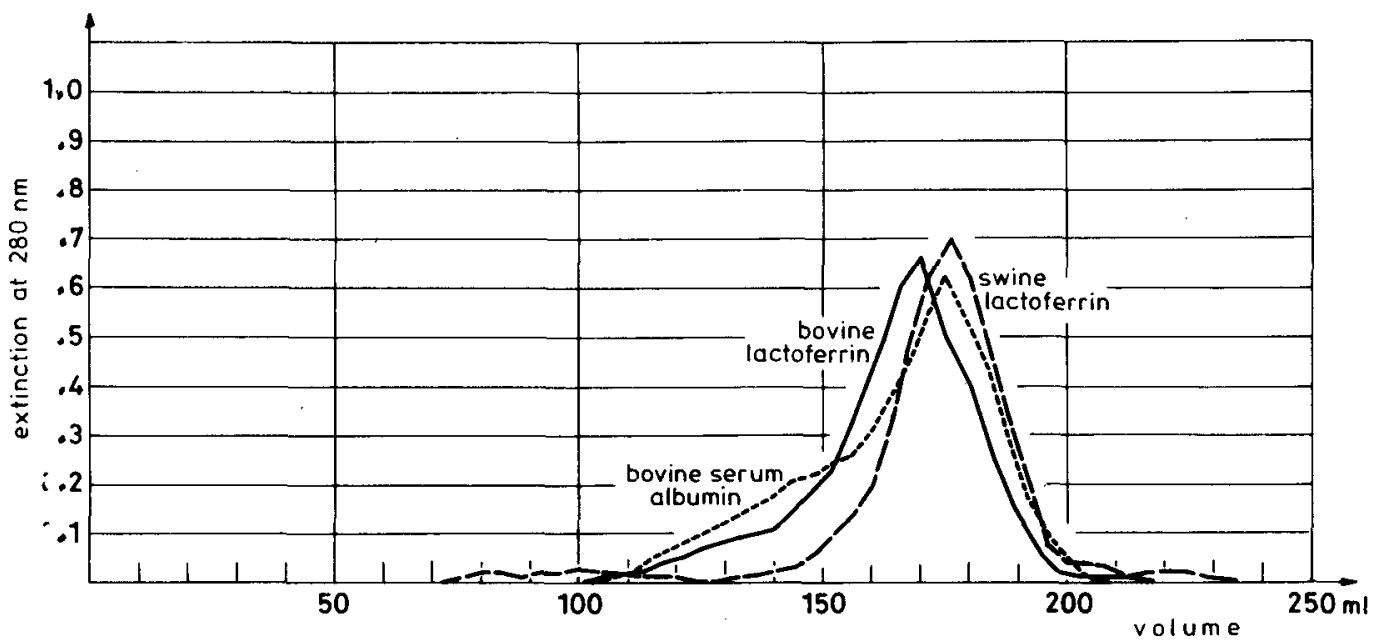

Figure 2. Elution pattern comparing swine lactoferrin with bovine lactoferrin and bovine serum albumin, showing absorbance of light at $280 \mathrm{~nm}$ in successive $5-\mathrm{ml}$ fractions of eluant taken from a column containing Sephadex G-200. 


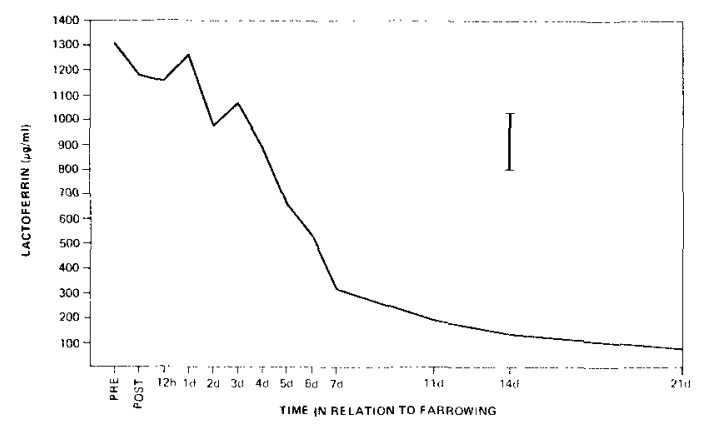

Figure 3. Mean lactoferrin concentration $(\mu \mathrm{g} / \mathrm{ml})$ in the colostrum and milk of nine sows during a $21-\mathrm{d}$ lactation. Samples were collected before farrowing (PRE), immediately after farrowing (POST), and $12 \mathrm{~h}$ to $21 \mathrm{~d}$ thereafter. The vertical bar shows twice the standard error of the difference.

$\mu \mathrm{g} / \mathrm{ml}$, vs 532 and $513 \mu \mathrm{g} / \mathrm{ml}$, averaged over the 13 sampling times).

The six additional sows studied at the time of farrowing showed relatively little variation in lactoferrin content from teat to teat. Mean levels for individual sows ranged from 1,208 to $1,577 \mu \mathrm{g} / \mathrm{ml}$, with standard errors of 56 to 150 . With teat position numbered from 1 (anterior) to 7 (posterior), two-way analysis of variance showed significant variation attributable to sows $\left(\mathrm{F}_{5,28}=11.13, \mathrm{P}<.001\right)$, but not to teat position $\left(\mathrm{F}_{6,28}=.517\right)$.

The rapidly decreasing concentration of lactoferrin during the first week of lactation might be explained by reduced synthesis of the protein and(or) increasing dilution of lactoferrin caused by increased synthesis of milk. Verdonck and Paredis (1980) noted that the antimicrobial activity of sows' colostrum and milk also declines during lactation. They attribute the effect to the decrease in the concentration of immunoglobulins in sows' milk, stating that lactoferrin is a more constant constituent. However, our results indicate that lactoferrin is not a constant constituent. This was also demonstrated in human milk by Nagasawa et al. (1972) and in bovine milk by Erhardt (1981).

In view of its known antimicrobial activity (Bullen et al., 1972), it is quite possible that lactoferrin is an important antibacterial constituent of sows' milk in the early stages of lactation, supplementing the effect of immunoglobulins (Wilson, 1974). It is interesting to note that the decrease in lactoferrin content corresponds with the development of the pig's endogenous capability to produce and secrete immunoglobulins into the intestinal lumen as described by Wilson (1974).

There may be an important role for lactoferrin in the development of milk replacers to be used in the artificial rearing of piglets. The nonspecific bacteriostatic activity of lactoferrin has been demonstrated in numerous investigations (Oram and Reiter, 1968; Bullen et al., 1972), and the mechanism of action shown to be based on the binding of $\mathrm{Fe}$ to the protein, thereby rendering it unavailable for bacterial growth. Because of the nonspecific activity of the lactoferrin from different species and the difficulty in obtaining large amounts of sows' milk, it is proposed to investigate the use of bovine lactoferrin in milk replacers for piglets. In view of the large variation among sows noted here, it would be useful to determine whether piglet survival is related to the lactoferrin concentration of the dam's milk. If so, this variable might be useful in genetic selection.

\section{Literature Cited}

Blanc, B. and H. Isliker. 1961. Isolement et caractérisation de la proteine rouge sidérophile du lait maternel: la lactoferrine. Helv. Physiol. Pharmacol. Acta 19:C13.

Bullen, J. J, H. J. Rogers and L. Leigh. 1972. Ironbinding proteins in milk and resistance to Escherichia coli infection in infants. Brit. Med. J. 1:69.

Butler, J. E. 1973. The occurrence of immunoglobulin fragments, two types of lactoferrin and a lactoferrin $I_{I^{2}}$-complex in bovine colostral and milk-whey. Biochim. Biophys. Acta 295:341.

Elliot, J. I., G. A. Lodge and T. G. Hartsock. 1978. Practical artificial rearing of neonatal piglets under non-isolated conditions. Can. J. Anim. Sci. 58:799.

Erhardt, G. 1981. Zusammenhange zwischen Zitrat und Lactoferrin in der Milch laktierender und nicht laktierender Kuhe sowie nach experimenteller Infektion der Milchdruse mit Staphylococcus aureus. Giessner Schriftenreihe Tierzucht und Haustiergenetik, Verlag Paul Parey, Hamburg und Berlin.

Harmon, J., F. L. Schanbacker, L. C. Ferguson and K. L. Smith. 1975. Concentration of lactoferrin in milk of normal lactating cows and changes occurring during lactation. Amer. J. Vet. Res. 36:1001.

Law, B. A. and B. Reiter. 1977. The isolation and bacteriostatic properties of lactoferrin from bovine milk whey. J. Dairy Res. 44:595.

Lowry, O. J., N. J. Rosebrough, A. L. Farr and R. J. Randall. 1951. Protein measurement with the folin-phenol reagent. J. Biol. Chem. 193:265.

Mancini, G., A. O. Carbonara and J. F. Heremans. 1965. Immunochemical quantitations of antigene by single radial immunodiffision. Immuno- 
chemistry 2:235.

Masson, P. L. and J. F. Heremans. 1971. Lactoferrin in milk from different species. Comp. Biochem. Physiol. 39B: 119.

Nagasawa, T., I. Kiyosawa and K. Kuwahara. 1972. Amounts of lactoferrin in human colostrum and milk. J. Dairy Sci. 55:1651.

Oram, J. D. and B. Reiter. 1968. Inhibition of bacteria by lactoferrin and other iron-chelating agents. Biochim. Biophys. Acta 170:351.

Roberts, T. K. and J. C. Boursnell. 1975. The isolation and characterization of lactoferrin from sow milk and boar seminal plasma. J. Reprod. Fertil. 42:579.

Schanbacher, F. L. and K. L. Smith. 1975. Formation and role of unusual whey proteins and enzymes: Relation to mammary function. J. Dairy Sci.
58: 1048 .

Scheidegger, J. J. 1955. Une micromethode de l'immuno-electrophorèse. Int. Arch. Allergy 7:103.

Senft, B. and F. Klobasa. 1971. Untersuchungen uber die kunstliche Aufzucht von Ferkeln. I. Der Einstaz von Rinderkolostralmilch und reifer Kuhmilch. Zuchtungskunde 43:371.

Senft, B. and F. Klobasa. 1973. Untersuchungen uber die Konzentration an Lactoferrin in Kolostralmilch und reifer Milch von Kuhen. Milchwissenschaft 28:750.

Verdonck, M. and F. Paredis. 1980. A comparative study of the in vitro antimicrobial activity of colostrum and milk in the pig. IRCS Med. Sci. $8: 287$.

Wilson, M. R. 1974. Immunologic development of the neonatal pig. J. Anim. Sci. 38: 1018. 